\title{
BARANG PUBLIK DAN EKSTERNALITAS PADA ERA OTONOMI DAERAH
}

\section{PUBLIC GOODS AND THE ERA OF REGIONAL AUTONOMY EXTERNALITIES}

\author{
Kristian Widya Wicaksono \\ Jurusan Ilmu Administrasi Publik Universitas Katolik Parahyangan \\ Jalan Ciumbuleuit No. 94, Bandung \\ E-mail: widya_wicaksono@yahoo.com
}

Diterima: 10 September 2012, Direvisi: 2 Desember 2012, Disetujui: 10 Desember 2012

\begin{abstract}
Abstrak
Era desentralisasi membuka peluang bagi Pemerintah Daerah (Pemda) untuk mengelola secara mandiri urusan domestiknya mulai dari proses formulasi, implementasi hingga evaluasi kebijakan serta program pembangunan yang sesuai dengan kebutuhan masyarakat setempat. Dalam menjalankan kewenangannya tersebut, Pemda diharapkan mampu mengelola secara efektif dan efesien sumber-sumber yang tersedia, mengatasi masalah publik seperti dampak buruk eksternalitas yang ditimbulkan akibat aktivitas pasar, mendiagnosa serta menangani kegagalan pasar (market flliure) dalam hal ini menyediakan barang publik (public goods) guna memenuhi kebutuhan masyarakat yang tidak mampu disediakan melalui mekanisme pasar.

Kata kunci: kegagalan pasar, barang publik, eksternalitas, desentralisasi, pajak dan kesejahteraan masyarakat
\end{abstract}

\begin{abstract}
Decentralization opportunities for local governments to manage their domestic affairs independently from the process of formulation, implementation and evaluation of development policies and programs to suit the needs of local communities. In exercising its authority, the government is expected to manage effectively and efficiently resources are available, such as the public address adverse externalities caused by market activity, diagnosing and addressing market failure in this case provides public goods to meet the needs of people who can not afford provided through market mechanisms.

Keywords: market failures, public goods, externalities, decentralization, tax and welfare
\end{abstract}

\section{PENDAHULUAN}

Semenjak tahun 2001 Bangsa Indonesia mulai menghadapi era baru yakni desentralisasi melalui pemberlakuan Undang-Undang Nomor 22 Tahun 1999 tentang Pemerintahan Daerah yang kemudian diperbaharui menjadi Undang-Undang Nomor 32 Tahun 2004. Era desentralisasi membuka peluang bagi Pemerintah Daerah (Pemda) untuk mengelola secara mandiri urusan domestiknya mulai dari proses formulasi, implementasi hingga evaluasi kebijakan serta program pembangunan yang sesuai dengan kebutuhan masyarakat setempat. Dalam menjalankan kewenangannya tersebut, Pemda diharapkan mampu mengelola secara efektif dan efesien sumber-sumber yang tersedia, mengatasi masalah publik seperti dampak buruk eksternalitas yang ditimbulkan akibat aktivitas pasar, mendiagnosa serta menangani kegagalan pasar (market failure) dalam hal ini menyediakan barang publik (public goods) guna memenuhi kebutuhan masyarakat yang tidak mampu disediakan melalui mekanisme pasar.

Hingga tahun 2008 ini pelaksanaan desentralisasi di Indonesia terus berkembang ke arah yang cukup konstruktif meskipun masih terdapat berbagai kendala di dalamnya seperti tarik-menarik keuangan antara daerah dan pusat melalui penetapan bagi hasil, penetapan pajak serta jenis retribusi. Secara makro masyarakat dapat merasakan perubahan yang cukup signifikan bila dibandingkan pada masa orde baru dimana pengelolaan pembangunan masih sangat bergantung dengan kebijakan pemerintah pusat. Saat ini, desentralisasi memungkinkan Pemerintah Daerah untuk merespon setiap perkembangan yang terjadi di tengah-tengah masyarakat. Apalagi dorongan demokratisasi menyebabkan masyarakat secara leluasa dapat memilih kepala daerahnya sendiri sesuai dengan aspirasinya. Hal ini semakin membuka peluang yang lebih luas bagi masyarakat untuk menuntut kepada pemerintah beserta aparaturnya untuk berperilaku kondusif terhadap permintaan publik.

Sebagaimana yang telah disinggung sebelumnya, bahwa pelaksanaan desentralisasi di Indonesia membawa dampak bagi daerah untuk menyediakan barang publik dan mengatasi implikasi buruk dari eksternalitas yang ditimbulkan oleh aktivitas pasar. Sebelum lebih jauh mengupas mengenai kedua hal tersebut, maka terlebih dahulu 
kita perlu menelaah lebih dalam konsepsi barang publik dan eksternalitas sehingga membantu kita dalam memahami fenomena empirisnya pada pelaksanaan desentralisasi di Indonesia.

\section{PEMBAHASAN}

\section{Memahami Barang Publik dan Eksternalitas}

Salah satu penjelasan yang cukup awal mengenai barang publik dikemukakan oleh Paul A. Samuelson dalam tulisannya yang berjudul The Pure Theory of Public Expenditure pada Review of Economic and Statistic (1954). Dalam tulisannya tersebut, Samuelson menyatakan bahwa ...(goods) which all enjoy in common in the sense that each individual's consumption of such a good leads to no subtractions from any other individual's consumption of that good...

Secara sederhana penjelasan Samuleson tersebut mencoba menguraikan bahwa karakterisitik utama barang publik adalah barang tersebut dapat dibagikan. Artinya, barang publik merupakan barang yang tersedia untuk semua orang dan bersifat noneksklusif. Dengan kata lain tidak ada persaingan yang terjadi diantara aktor-aktor yang mencoba untuk mengakses barang publik tersebut. Lebih jauh dalam tulisannya tersebut diuraikan bahwa barang publik dibayar atau disediakan melaui hasil pungutan pajak dan pinjaman yang dilakukan pemerintah. Selain itu harganya bisa dinyatakan dalam tingkat pajak (taxation) yang diperlukan untuk membiayai produksi barang-barang tersebut. Sedangkan barang privat dibayar melalui sistem harga yang berlaku di pasar.

Sebuah barang publik mungkin saja merupakan barang yang sesuai dengan jenis-jenis kriteria yang ditetapkan oleh Samuelson tadi, tetapi mungkin pula barang publik yang tersedia bagi semua orang tersebut tergantung pada kriteria yang ditetapkan dalam suatu kebijakan misalnya manfaat yang dapat didistribusikan kepada kelompok atau tipe individu tertentu saja (beneficiary group). Hal inilah yang kemudian mempertegas pembedaan antara konsep Public Goods dengan Publicly Provided Good. Dukungan penjelasan mengenai pembedaan kedua konsep tersebut dikemukakan oleh Musgrave dalam bukunya yang berjudul The Theory of Public Finance (1959). Musgrave menyatakan bahwa apa yang dinamakan "barang-barang yang bermanfaat" bisa jadi sebagian tidak masuk kategori barang publik karena barang tersebut tidak memenuhi kualifikasi atau standar non-eksklusf.

Studi lainnya mencoba untuk mengangkat penjelasan mengenai siklus barang Publik. Studi ini dilakukan oleh Frey dalam bukunya Modern Political Economy (1978). Dalam karyanya tersebut Frey mengatakan bahwa terdapat sebuah siklus dalam permintaan barang publik. Oleh karenanya, sektor publik atau privat akan berubah pada kurun waktu tertentu untuk merespon interaksi dari para pemilih (voters), pemerintah, civil servant, dan produsen. Siklus tersebut dapat dilihat dalam gambar berikut ini:

Secara makro dapat dikemukakan bahwa barang publik (public goods) adalah barang atau jasa yang tersedia untuk semua orang. Pola penjelasan seperti ini memang cukup mudah untuk dipahami, hanya saja tidak cukup membantu manakala kita diminta untuk menjelaskan secara detail bagaimana karakteristik barang publik itu sesungguhnya serta apa yang membedakannya dari barang privat.

Pendekatan ekonomi memberikan kita penjelasan yang lebih memadai mengenai barang publik. Dalam pendekatan tersebut dijelaskan bahwa barang publik memiliki dua karakteristik utama yakni nonrivalry dan nonexcludability (Buchanan, 1967).

Konsepsi nonrivalry lebih mudah dipahami dalam konteks ketika suatu barang sedang dinikmati atau dikonsumsi. Artinya, nonrivalry mengekspresikan bahwa sebuah barang dapat dikonsumsi secara bersamaan (waktu dan tempat yang sama) oleh beberapa pihak tanpa mengurangi atau menghilangkan jumlah yang tersedia untuk dikonsumsi bagi pihak lainnya (Cowen, 1992). Misalnya, saat kita sedang menikmati udara segar di sore hari maka di saat yang bersamaan orang lain yang berada di sekitar kita yang dapat turut merasakan udara segar tersebut tanpa harus saling berebutan atau saling menghilangkan hak antara yang satu dengan lainnya. Dengan demikian, dapat dikatakan bahwa udara segar merupakan barang

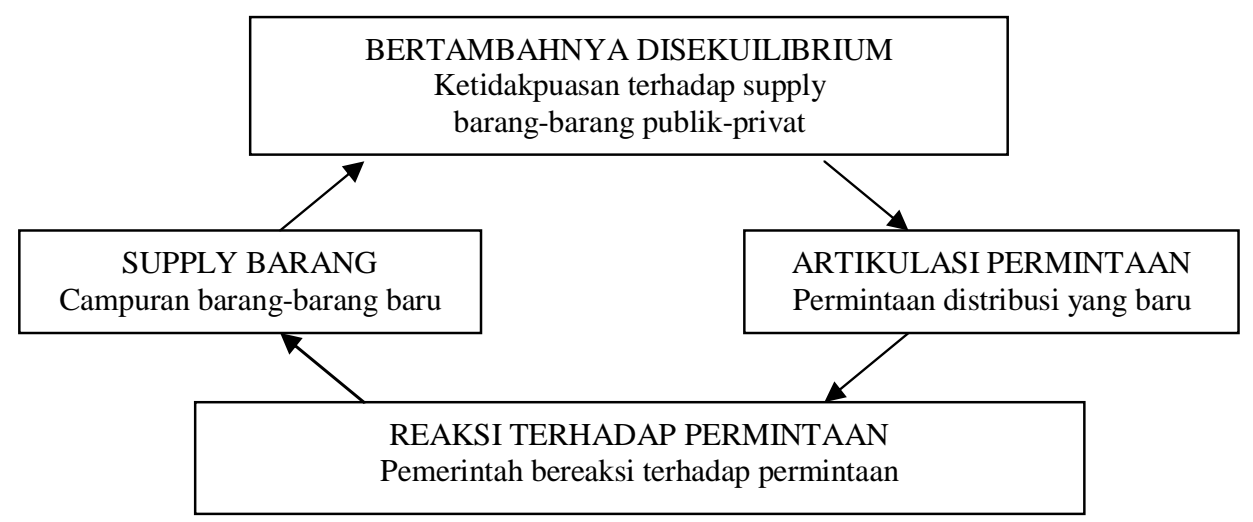

Sumber: diadaptasi dari Frey (1976: 116-21) 
publik murni.

Berdasarkan penjelasan di atas kita dapat menangkap bahwa secara tersirat nonrivalry merujuk pada ketiadaan kompetisi (noncompetition) dalam mengonsumsi suatu barang dan jasa.

Dimensi lainnya yang menjadi karakteritik utama dari barang publik adalah nonexcludability. Hampir mirip dengan nonrivalry, konsepsi ini juga harus dilihat dalam konteks konsumsinya (Cowen dan Crampton, 2003). Artinya, tidak ada batasan atau pelarangan untuk membatasi orang lain dalam mengonsumsi suatu barang dan jasa meskipun mereka tidak membayar sesuatu apapun dalam mengonsumsi barang tersebut. Dengan kata lain, tidak ada satu pun pihak yang dapat melarang seseorang untuk menghirup udara segar dengan alasan orang tersebut tidak membayar sejumlah uang untuk dapat turut merasakan udara segar tersebut mengalir di saluran pernafasannya.

Berangkat dari penjelasan tersebut dapat dipahami bahwa tidak ada pengecualian atau diskriminaisi terhadap pihak manapun dalam mengonsumsi barang publik. Artinya, setiap warga negara diberikan kesempatan yang sama dalam mengakses barang publik.

Sedangkan Eksternalitas atau yang lazim disebut sebagai spillover effects terjadi pada saat tindakan seseorang memberikan efek kepada orang lain dan biaya serta keuntungan yang dimunculkannya tidak dapat direfleksikan dalam harga pasar (Ulbrich: 2003). Dalam pernyataan yang lebih sederhana dapat dikemukakan bahwa eksternalitas merupakan beban biaya atau keuntungan yang ditanggung oleh pihak ketiga yakni pihak yang berada di luar transaksi. Beban biaya yang menjadi tanggungan pihak ketiga tersebut tidak dapat diklaimkan kepada pembuat efek atau pihak ketiga juga tidak dapat dibebani suatu tagihan atas manfaat atau keuntungan yang mereka peroleh atas spill over effect tersebut.

Berbeda dengan konsep-konsep sebelumnya, konsep eksternalitas tidak saja dilihat pada proses konsumsinya melainkan juga dapat ditinjau pada proses produksinya. Misalnya eksternalitas berupa polusi udara yang ditimbulkan oleh suatu pabrik karena kebutuhan pembaran dalam proses produksi suatu barang. Polusi udara tersebut kemudian menyebabkan menurunnya kualitas udara yang dihirup oleh masyarakat di sekitar wilayah pabrik tersebut sehingga mereka terkena gangguan kesehatan pernafasan. Beban ini tentunya akan sulit apabila diklaimkan secara langsung kepada pemilik pabrik, maka dari itu, pemerintah bisa menerbitkan perangkat kebijakan yang mengatur mengenai beban tarif bagi pabrik yang mengeluarkan asap dan mencemari udara selanjutnya beban tarif retribusi tersebut digunakan untuk meningkatkan kualitas layanan kesehatan bagi masyarakat. Namun, dalam perkembangannya saat ini pelaku pasar seperti pemilik pabrik memiliki semacam obligasi untuk melakukan semacam kegiatan karitatif bagi masyarakat melalui sebuah program yang dinamakan Corporate Social Responsibilities (CSR).

\section{Permasalahan Pemda dalam Penyediaan Barang Publik dan Eksternalitas}

Pada era desentralisasi tuntutan untuk menyediakan barang publik yang lebih berkualitas semakin membuncah pada level pemerintah daerah. Secara mendasar melalui desentralisasi, maka penyediaan barang publik dapat mengikuti Perencanan yang spesifik menggunakan informasi yang detail dan mutakhir dan hanya tersedia secara lokal. Oleh karenanya, secara ideal barang publik yang disediakan oleh pemerintah daerah sedianya memang menjawab kebutuhan masyarakat. Namun di tingkat praksis hal ini belum dapat teruwjud sebab seringkali terjadi inkonsistensi kebijakan pengadaan barang publik di tingkat pemerintah lokal yang dinilai bertentangan dengan kebijakan Pemerintah Pusat. Kasus pengadaan alat berat di Provinsi Jawa Barat yang ditujukan untuk memenuhi kebutuhan publik guna peningkatan kualitas layanan pembangunan dan pemeliharaan infrastuktur justru berujung pada penahanan Danny Setiawan selaku Mantan Gubernur Jawa Barat oleh Komisi Pemberantasan Korupsi. Landasan yang digunakan dalam penahanan mantan Gubernur Jawa Barat tersebut adalah inkonsistensi kebijakan antara Perda tentang APBD 2004 dengan Keppres 80 Tahun 2003 tentang Pedoman Pelaksanaan Pengadaan Barang dan Jasa.

Di sisi lain, permasalahan ruang otonomi bagi daerah untuk membentuk perencanaan bagi pengadaan barang publik secara lokal juga dapat memicu ketidakadilan regional. Misalnya layanan pendidikan dan kesehatan gratis di beberapa daerah di Tanah Air dapat memicu perpindahan penduduk dari suatu daerah yang tidak mampu menyelenggarakan layanan tersebut ke daerah yang mampu menyediakan layanan dasar tadi. Oleh karenanya, proses penyediaan barang publik juga perlu memperhatikan aspek keadilan bagi daerah lainnya, buka saja bertumpu pada kemampuan daerah itu sendiri. Pada posisi inilah peran Pemerintah Pusat melalui Dana Alokasi Umum dan Dana Alokasi Khusus menjadi penting bagi terwujudnya keadilan di seluruh daerah di Tanah Air.

Dalam alam desentralisasi juga terbuka masalah lainnya yakni mengenai pengelolaan asset daerah. Sebagaimana yang kita ketahui bersama bahwa asset daerah merupakan segala kekayaan yang pengadaannya menggunakan anggaran publik (sehingga layak disebut sebagai barang publik) namun pemanfaatannya dapat sepenuhnya digunakan oleh publik tanpa harus bersaing (non-rivalry) dan ada pengecualian (non-excludability) tetapi juga untuk barang tertentu mungkin hanya dapat dimanfaatkan untuk kalangan tertentu saja sebagai akibat jabatan atau pelaksanaan tugas pokok dan fungsi (tupoksi). Karena pengadaan barang tersebut menggunakan anggaran publik dimana pajak dan pinjaman menjadi bagiannya maka asset pemerintah memiliki sistem 
standar nilai tukar tertentu meskipun asset tersebut berfungsi untuk pelayanan dan dapat diakses berbagai pihak.

Saat ini kita dapat melihat betapa manajemen asset daerah kita masih bermasalah. Ada dua masalah utama yang perlu untuk mendapat perhatian secara khusus, pertama dari segi pemeliharaan dan kedua dari segi pembangunan, penguatan serta peningkatan sistem informasi asset daerah.

Masalah pertama adalah pemeliharaan asset daerah. secara jernih kita terlebih dahulu mencoba untuk menyisihkan terlebih dahulu aspek-aspek yang berkaiatan dengan pengadaan asset tersebut sebab akar masalahnya justeru terletak pada pemeliharaan bukan pada pengadaan. Asumsi ini mejadi semakin menemukan jati kebenarannya manakala pola penggunaan asset daerah dianggap sebagai barang habis-pakai semata atau bahkan yang lebih kronis kita menyatakannya sebagai tidak adanya rasa memiliki aparatur terhadap asset daerah sehingga penggunaannya menjurus pada arah serampangan. Hal ini diakibatkan pemikiran bahwa suatu saat mereka (pejabat pemerintah) akan meninggalkan jabatannya, maka tidak perlu ada obligasi moral untuk menjaga dan memelihara asset tersebut. Meskipun demikian, dari segi pengadaan pun nampak bahwa seringkali asset disediakan tanpa perencanaan yang jelas sebab pertumbuhan dan penyusutan asset daerah tidak dikalkulasikan secara matang sehingga masalahmasalah yang kompleks justru muncul di belakang hari dan semakin membebani anggaran pemerintah daerah.

Dalam konteks kekinian maka kita dapat melihatnya dalam bentuk praktek ketidakseriusan dalam memutakhirkan asset-asset tertentu yang terus berubah sesuai dengan konteks kekinian atau perubahan zaman misalnya teknologi infomasi. Padahal organisasi pemerintah seharusnya reponsif terhadap perkembangan situasi sebagaimana dimensi administrasi publik yang menuntut operasionalisasi yang efektif dan efesien. Pemerintah harus menjadi agen yang akomodatif terhadap konteks kekinian tersebut tanpa harus terjebak dalam penghamburan dana dalam anggaran publik tetapi tampil taktis dan strategis. Operasionalisasi konsep ini hanya akan terwujud dalam pemerintahan yang digerakkan oleh misi bukan sekedar prosedural. Maka pengembangan organisasi kemudian menjadi tuntutan, dimana budaya yang dibangun tidak lagi mengacu pada paradigma organisasi tipe abad pertengahan seperti esselonisasi struktural tetapi membangun agen-agen fungsional sehingga birokrasi pemerintah menjadi kaya fungsi bukan kaya struktur. Hal inilah yang akan menjadi jawaban untuk konteks masyarakat berubah sebagaimana yang diuraikan oleh Max Weber sebagai pembentuk masyarakat rasional atas dorongan konsekuensi industrialisasi sehingga menuntut lahirnya birokrasi.

Masalah kedua yang harus dipecahkan adalah sistem informasi asset, artinya di luar konteks pemeliharaan perlu dilakukan pengawasan terhadap asset dengan sistem pemuktahiran pencatatan yang akurat mengenai perkembangan nilai asset serta penggunaannya, misalnya dengan menggunakan analisis time series untuk menilai efektivitas penggunaan asset. Selain itu sistem pengawasan dapat didekati dari paradigma penjaluran penggunaan asset artinya apabila terdapat aktivitas yang sekiranya dapat menimbulkan kerugian sebagai inkonsistensi pemanfaatan asset maka perlu dilakukan pengembalian pada jalur yang semestinya. Untuk mengoperasionalisasikan penyelesaian masalah tersebut maka perlu dibangun obligasi moral dimana pengawas asset bertindak independen dan tidak bermalas-malasan untuk melakukan pemuktahiran data asset. Saat ini yang mendesak untuk dilakukan pemerintah adalah membuang jauh-jauh rasa malas tersebut dan dengan serius melakukan pendataan ulang terhadap asset yang ada termasuk menyelidiki secara tuntas asal-usul asset tersebut sehingga tidak mengundang kontroversi seperti yang terjadi dengan dinas peternakan di Jalan Ir. H. Djuanda (Dago), Gedung Sate di Jalan Diponegoro atau kasus kepemilikan tanah SMA Negeri 22 Bandung. Sehingga pertanggungjawaban kepemilikan dan pemenfaatan secara efektif asset-asset tersebut dapat diselenggarakan sebagai bentuk obligasi moral pemerintah yang telah menggunakan anggaran publik dalam pengadaannya.

Aspek lainnya perlu dibahas dalam hal penyelenggaraan otonomi daerah adalah upaya-upaya pemerintah dalam penanganan dampak buruk eksternalitas. Dampak buruk eksternalitas akibat aktivitas pasar seringkali muncul di tengah-tengah masyarakat adalah pembuangan limbah pabrik yang mencemari lingkungan. Masalah ini dahulu diatasi oleh pemerintah pusat, namun seiring dilaksanakannya kebijakan desentralisasi maka Pemerintah Daerah diberi kewenangan untuk melakukan pengawasan dan pengendalian terhadap aktivitas pembuangan limbah tersebut. Salah satu permasalahan yang bisa dicermati dari pelimpahan kewenangan seperti ini adalah bagaimana aparatur pemerintah daerah kemudian meingkatkan kapabilitasnya sehingga proses pengawasan dan pengendalian pencemaran lingkungan melalui buangan limbah pabrik dapat berjalan dengan efektif dan efesien. Sebab, seringkali proses pelimpahan kewenangan seperti ini tidak diikuti dengan transfer of knowledge akibatnya dampak buruk eksternalitas tidak tertangani dengan baik sehingga masyarakat menjadi dirugikan. Kasus seperti ini bisa diamati di Kawasan Kabupaten Bandung, memburuknya kualitas air dan degradasi lahan pada Sungai Citarum hingga saat ini justeru menunjukkan perkembangan yang semakin memprihatinkan. Pemerintah Kabupaten Bandung dan Pemerintah Jawa Barat mengalami kesulitan untuk melakukan pemulihan pada Daerah Aliran Sungai Citarum. Salah satu program yang telah dilaksanakan dan saat ini masih berjalan adalah Rehabilitasi Hutan 
dan Lahan melalui SK Gubernur No 915.2/KEP.40DAL-PROG/2002 Tentang Citarum Bergeutar, akan tetapi hasilnya masih kurang optimal sebab apalikasi teknologi pengawasan dan pengendalian atas limbah buangan pabrik masih lemah sehingga tingkat pencemaran air masih tinggi. Akibatnya masyarakat dirugikan karena minimnya pasokan air bersih. Belum lagi bila musim penghujan mulai tiba dan air sungai meluap berbagai penyakit mulai mendera masyarakat karena luapan air citarum membanjiri pemukiman penduduk.

Kasus kerusakan lingkungan yang diakibatkan oleh aktivitas usaha pertambangan juga terjadi di beberapa daerah di Indonesia diantaranya PT. Freeport Indonesia di Papua dan penambangan emas PT. Newmont Minahasa Raya di perairan Buyat, Sulawesi utara. Menurut catatan Wahana Lingkungan Hidup Indonesia sepanjang tahun 1995 hingga 2000 PT Freeport telah menghasilkan 420 juta ton sampah industri yang 95 persennya dibuang ke Lembah Wanangon di wilayah Grasberg, Papua. Berdasarkan laporan tersebut maka Walhi menyimpulkan bahwa PT. Freeport berkontribusi terhadap kerusakan lingkungan pada sungai-sungai di wilayah Papua terutama danau Wanangon. Sempat pula terjadi kebocoran pada tempat penampungan sampah insdutri milik PT. Freeport di Danau Wanangon. Banjir sampah pun terjadi sehingga mengakibatkan empat orang pekerja Freeport hilang. Selain banjir sampah, kebocoran ini juga menyebakakn banjir hingga radius 16 kilometer. Banjir paling parah melanda Desa Banti. Hal yang sama terjadi PT. Newmont dimana kebocoran saluran penambangan menyebabkan pencemaran terhadap air di sekitar kawasan penambangan. Hal ini kemudian berimbas terhadap kualitas kesehatan masyarakat karena mereka menfaatkan air tersebut untuk keperluan sehari-hari. Sayangnya upaya untuk mengani dampak eksternalitas seperti ini masih kurang optimal. Kedua kasus di atas pernah dibawa ke pengadilan namun putusan hakim atas perkara ini tidak begitu memuaskan bahkan sanksi yang diberikan pun cenderung abstrak. Misalnya untuk kasus Freeport mereka hanya diminta untuk memperhatikan faktor-faktor lingkungan seperti yang dianjurkan Bapedal. Padahal berdasarkan data Jaringan Advokasi Tambang dinyatakan bahwa operasi pertambangan menyumbang 10 persen kerusakan hutan di Indonesia, tentunya sanksi yang diterapkan tidaklah sebanding dengan kerusakan yang ada. Belum lagi bila dibandingkan dengan profit yang diperoleh PT. Freeport. Hal ini mengindikasikan bahwa proses penanganan dampak buruk eksternalitas di daerah kurang mendapat porsi yang baik sehingga untuk berbicara ke arah yang lebih jauh seperti penerapan kompensasi bagi pihak-pihak yang dirugikan pun masih sangat prematur untuk dibahas secara mendetail.

\section{PENUTUP}

Berangkat dari uraian yang disampaikan dalam makalah ini, maka yang penyediaan barang publik hendaknya memperhatikan hal- hal, seperti pertama, penyediaan barang publik hendaknya disedikan atas permintaan publik guna mengatasi masalah yang ditimbulkan akibat aktivitas pasar atau yang dikenal dengan istilah kegagalan pasar (market failure).

Kedua, ada konteks pelaksanaan desentralisasi, Pemerintah Daerah diharapkan mampu meningkatkan kapabilitasnya dalam hal membaca situasi masalah publik yang disebabkan kegagalan pasar khususnya eksteralitas negatif yang sering kali membebani masyarakat. Peningkatan kapailitas ini dimungkinkan melalui upaya pro-aktif pemerintah untuk mengatasi dampak buruk eksternalitas yang dirasakan oleh masyarakat.

Ketiga, upaya untuk mengatasi dampak buruk eksternalitas oleh Pemerintah Daerah hendaknya tidak hanya bertumpu pada penerbitan regulasi melainkan pula ketepatan pemerintah dalam merancang agar pihak ketiga yang dirugikan dapat memperoleh kompensasi yang tepat. Permasalahannya pemberian kompensasi yang tepat ini bergantung pada pengetahuan serta informasi yang dimiliki oleh pemerintah atas penyebab dan akibat yang ditimbulkan dari kegagalan pasar. Di sisi lain, perlu dilakukan upaya pemberdayaan agar masyarakat juga menyuarakan keluhan mereka atas dampak buruk eksternalitas yang mereka alami seperti pada kasus Freeport di Papua atau PT Newmont di Minahasa. Berdasarkan tingkat kerugian tersebut pemerintah dapat mengenakan Pigovian Tax yakni pajak yang dipungut untuk mengoreksi eksteranlitas negatif yang disebabkan oleh aktivitas pasar.

Pada akhirnya public goods hendaknya juga mengutamakan kualitas sehingga memberikan kepuasan kepada masyarakat di daerah

\section{DAFTAR PUSTAKA}

Buchanan, James M. 1967. "Public Goods in Theory and Practice: A Note on the Minasian-Samuelson Discussion." Journal of Law and Economics 10: 193-197.

Cowen, Tyler. (1992. Public Goods and Market Failures. New Brunswick, N.J.: Transaction Publishers

Cowen, Tyler, and Eric Crampton. 2003. Market Failure or Success: The New Debate. Cheltenham, U.K.: Edward Elgar.

Frey, B.S. 1978. Modern Political Economy. Oxford: Martin Robertson.

Musgrave, R. A. 1959. The Theory of Public Finance. New York: McGraw-Hill.

Samuelson, P.A. 1954. "The Pure Theory of Public Expenditure." Riview of Economic and Statistic. 37:35-46.

Ulbrich, Holley H. 2003. Public Finance: In Theory And Practice. Ohio: Thomson South Western. 
286 | Jurnal Bina Praja | Volume 4 No. 4 Desember 2012|281 - 286 